\title{
Innovation of Small and Medium-Sized Enterprises from the Perspective of Globalization
}

\author{
Roman Juris ${ }^{1, *}$, Peter Adamko ${ }^{2}$, and Radovan Savov ${ }^{3}$ \\ ${ }^{1}$ University of Zilina, Faculty of Operation and Economics of Transport and Communications, \\ Department of Economics, Univerzitna 1, 01026 Zilina, Slovakia \\ ${ }^{2}$ University of Zilina, Faculty of Operation and Economics of Transport and Communications, \\ Department of Quantitative Methods and Economic Informatics, Univerzitna 1, 01026 Zilina, \\ Slovakia \\ ${ }^{3}$ Slovak University of Agriculture in Nitra, Faculty of Economics and Management, Department of \\ Management, Tr. A Hlinku 2, 94976 Nitra, Slovakia
}

\begin{abstract}
.
Research background: The presented paper deals with the support of innovative activities of small and medium enterprises in the Slovak Republic. The topicality of the issue is based on the knowledge that small and medium-sized enterprises can respond quickly and effectively to customer requirements and thus to changes resulting from changes in the market. In the era of globalization, the knowledge economy based on three key factors prevails in developed countries - science and research, the quality of human capital and innovative entrepreneurship, which focuses on creating the conditions for the practical use of knowledge, for projecting it into innovation. The aim of the paper is based on theoretical knowledge, analysis of support for innovative activities of small and medium enterprises by the state in the conditions of the Slovak Republic, their readiness to invest in research and development to propose a streamlining support scheme for small and medium enterprises.

Purpose of the article: The determinant of the future sustainable prosperity of the Slovak Republic, as a small open economy, must be the ability of the economy to respond flexibly to global changes and demand.

Methods: The article we used the method of synthesis, the method of abstraction, the method of generalization, the method of description, explanation.

Findings \& Value added: The output of the dissertation is an evaluation of the overall state of current support for innovative activities in small and medium-sized enterprises and a proposal for a possible streamlining of this support from the aspect of entrepreneurs themselves.
\end{abstract}

Keywords: Innovation; Support for innovative activities; Small and medium - sized enterprises; Support for SMEs

\footnotetext{
*Corresponding author: roman.juris@fpedas.uniza.sk
} 
JEL Classification: $A 11 ; A 14 ; B 16$

\section{Introduction}

Small and medium-sized enterprises are an integral part of the Slovak economy with a share of approximately three-fifths in gross domestic product. They are given key importance as a source of ideas, new products and, above all, job opportunities. Due to the high competition in the European market, our small and medium-sized enterprises must dynamically meet the ever-increasing demands of customers for goods and services. The research focused on the innovative activity of companies, the use of information technology in business and the role of design in increasing the competitiveness of small and mediumsized enterprises.

The National Agency for the Development of Small and Medium-sized Enterprises (NADSME) is established to support the development and growth of small and mediumsized enterprises in the Slovak Republic. One of its objectives is to improve the business environment, in particular by removing administrative and legislative barriers to free enterprise, which is a nationwide form of aid that does not discriminate but favor specific undertakings and does not distort competition.

Technological innovations include new products and processes, but also significant technological changes to products and processes.

Product innovation is the introduction of goods or services that are new or significantly improved in terms of their characteristics or their intended use. This includes significant improvements in technical specifications, components and materials, software or other performance characteristics. Product innovations can use new knowledge or technology or be built on new uses or combinations of existing knowledge or technology. The term product is used to cover goods and services.

Organizational innovation is a change in the structure of the company. It includes changes in managerial or organizational methods in relation to work and work organization, job organization and changes in the organization of external relations. The goal of organizational innovation is to accelerate the response to the identified needs of the customer.

Marketing innovation is the introduction of new or significantly improved product (packaging) design or sales methods to increase the attractiveness of products and services or to enter new markets. These innovations include significant changes in the way products and services are traded, including design and packaging changes.

\section{Methods}

The development of information technologies is causing a revolution around the world, their spread to all areas of economic and social life is causing the transformation of today's societies into information societies. Information technologies enable more efficient management of the company and at the same time are a gateway for gaining new contacts and communication with business partners. The latest survey therefore focused, among other things, on mapping the prevalence of the use of IT in business in small and medium-sized enterprises in Slovakia. Many kinds of research has suggested that innovation is positively linked to business performance and that it acts as an intermediary between organizational variables and financial performance measured by earnings achieved [1].

There are also other forms of activities that are focused on the self-development of companies, not only those that are most clearly identifiable from the outside and through which small and medium-sized enterprises increase their competitiveness, such as. technological innovations, product or service innovations. In innovation management, it is crucial to know the incentives or factors that, in many cases, provide the fundamental drivers 
of earnings, competitive advantage and the sustainable growth of businesses while also measuring their effectiveness [2]. Thanks to them, small and medium-sized enterprises improve the quality of their products or services and increase their competitiveness on the market. The selected economic, political, social and technological factors have an impact on the QBE in Slovakia [3]. The latest survey focused on the use of designers' work in product development and also on the willingness of entrepreneurs to cooperate with other organizations, companies, science and technology institutions. The business environment is a profound concern for the state and institutions to make it encouraging to boost entrepreneurship [4].

\section{Results}

Small and medium-sized enterprises in Slovakia form a key segment of the business sector and are the backbone of the economy and the basis of the country's competitiveness. A favorable business environment and the provision of appropriate forms of support are important preconditions for the successful development of small and medium-sized enterprises, as small and medium-sized enterprises usually have limited resources and are significantly more sensitive to the existence of various barriers to entrepreneurship such as large enterprises. The major well-known food companies from Finland, U.S.A. and other countries started opening their manufacturing facilities and sales outlets within the Russian territory. The local production of agricultural products has also experienced a revival [5]. A number of support measures are implemented in the conditions of Slovakia, the direct or indirect goal of which is also the support of small and medium-sized enterprises. ndustry 4.0 strategies may shape the entire business system through reorganizing the procedures of designing, manufacturing, distributing, and getting rid of products [6]. Creating new as well as further developing support tools for entrepreneurs can help sustain economic growth and boost employment in the long run.

The fact that many entrepreneurs lack experience in organizing, managing, creating a corporate culture, controlling strategic decision-making and communicating with foreign partners is negatively reflected in practice. They also lack a lot of economic and legal knowledge, especially often changing legislation is difficult to understand for such entrepreneurs.

From the point of view of R\&D funding, a long-term trend has been observed in Slovakia, according to which the research system is increasingly dependent on European resources and national funding is declining. The first ways to capture Earnings Management are based on graphical methods based on time-series data [7]. At the beginning of this century, the main investor in research in Slovakia was the public sector (Slovak government). Since our accession to the EU and especially since 2008, foreign resources have become more important, with the European Commission being the main foreign provider of funding to the Slovak research and innovation system. This was mainly related to the approach to the EU Structural Funds, which began to be significantly implemented this year, mainly through the OP Research and Development and partly also the OP Competitiveness and Economic Growth [8]. The Slovak government took advantage of European resources to fund research and innovation and reduced national support, despite the fact that the Structural Funds were only intended to be a complementary instrument to state funding.

Cooperation between the industrial environment and the academic community is the Achilles heel of the Slovak research and innovation system. The weak connection between the public sphere, research institutions and private companies is evident mainly from the low number of public-private publications and in the below-average results of indicators of commercial and non-commercial research outputs in Slovakia. These two spheres remain largely isolated. National sources mainly provide institutional funding for universities and 
the Slovak Academy of Sciences, while private sources support research for companies. The Agency for the Support of Research and Development implements several cooperation programs for Slovak companies and universities, resp. research institutions. However, the Agency's overall budget is low and national project funding is dominated by EU support for research infrastructure and national institutional support. Overall, measures to improve cooperation between business and academia are progressing slowly and showing shortcomings that could lead to an increased degree of interconnectedness and thus to a higher innovation engagement of SMEs themselves.

The quality and quantity of research and development and innovation infrastructure in Slovakia has long been neglected. There was a significant change in the programming period 2007-2013, when research and development capacities were built in Slovakia, mainly from the EU structural funds. EU support was focused on modernizing existing and building new research infrastructure. Support from EU funding for research and development has led to the completion of physical research and innovation infrastructure, but there is a lack of sufficient funding for maintenance and human resources.

Industrial sector investment in $R \& D$ is too low to significantly increase innovation performance [9]. There is also very little progress in innovation due to below-average private investment in this area by SMEs. Business research and development in Slovakia is one of the weakest in the EU and focuses on medium and high-tech production, where multinational companies dominate. The biggest challenge in this direction is the dual economy, which affects productivity, innovation outputs and investment in research and development [10]. The dual economy is a barrier to the development of a private research and development system that limits domestic research and development activities for the benefit of foreign multinationals with high productivity. To prevent a rapid denigration and to prevent the outflow of foreign capital, various efforts are being zealously implemented [11].

On the one hand, there are large international companies operating in Slovakia, but they lack domestic research activity, on the other hand, Slovakia has a low share of innovative companies from the ranks of domestic companies. Slovak entrepreneurs gave the economic factors a higher rating than Czech entrepreneurs. Similarly, Slovak entrepreneurs rated the importance of the Central Bank in establishing a stable business environment and the role of commercial banks in financing business needs more positively [12]. A large number of small and medium-sized enterprises in Slovakia have no research activities due to costs and potential risks. Interestingly, the financial crisis does not impact the performance of Italian gambling SMEs and some business segments, such as bingo, perform even better during the crisis [13]. Investments of Slovak SMEs in research and development are low, while generating few and below-average commercial outputs. In other words, market participants (owners, creditors, suppliers, subscribers, employees, competitors, the state, etc.) [14]. As a result, very little progress has been made on innovation, as confirmed by the annual EIS Innovation Performance Reviews.

\section{Discussions}

The current system of SME support in Slovakia is relatively complex, but opaque, it includes a number of actors who deal with the issue of SME support and is also characterized by complex links. The crunch hit all financial sectors with unanticipated severity [15].

The tasks of central state administration bodies are concentrated mainly around policymaking and fundraising. Specialized agencies, banking institutions and funds, serve mainly for the implementation of these policies, although their initiators and founders are state administration bodies, respectively. interest, professional and professional organizations. There are several institutions at different levels in the field of SME support. 
The European Commission and its individual Directorates-General (DGs) play the most important role at EU level. The Directorate-General for Growth (DG GROW) is the most important in terms of SME support. The lack of capital is due to the lack of own deposits, but also to the difficulty of obtaining foreign funds because they are not able to guarantee their repayment. The loan source is very expensive, which puts at risk the regular repayment of principal and high interest. Lack of capital causes small and medium-sized enterprises to lag behind with state-of-the-art technology and technology and thus a lower ability to compete in domestic and foreign markets. Every corporation has an economic and moral responsibility to its stockholders to perform well financially. Unrealistic ideas about the amount of investment funds for business development and unrealistic ideas about the amount of investment benefits often lead to undercapitalization of investment projects, prolonged investment construction and jeopardize the return on investment. In the normal course of business, the problem is the lack of cash needed to cover liabilities. The need to secure the cash flow for the day-to-day business leads entrepreneurs to operational management and diverts their attention from the prospective solution of tasks. Slovak entrepreneurs gave the economic factors a higher rating than Czech entrepreneurs. Many entrepreneurs are too costly to start their business, but are investing more in exterior, interior, expensive cars than in business content, which would usually result in the company being equipped with highquality technology and equipment and equipping workers with work equipment, protective equipment, and information. Also, entrepreneurs prefer short-term investment rather than creating long-term savings and deferred investment in larger development projects, especially for fear of currency depreciation. Lack of information on competitors and customers results in oversized production capacity. Another reason may be to offer uninteresting products. The economic consequence is the cost increase as well as the underutilisation of fixed costs. Businesses do not have an impact on the removal of external barriers, but we believe that they are able to mitigate these impacts by their activity. We would propose to eliminate the reduced purchasing power of the population and the barriers that arise in a sectoral environment by investing in advertising and marketing (especially market research), as SMEs often save on marketing, which reduces consumers' awareness of the products they produce. customer unfavourable situation. Within the internal barriers we have identified mainly the unwillingness of management to engage in long-term investments in uncertain economic situations, especially in the area of technology. It should be noted, however, that while we have been waiting for a longer return on investment, these investments have a long-term impact on increasing labor productivity, increasing machine performance, increasing production capacity utilization. At the same time, however, we must consider whether the production produced will achieve the desired sales. Increasing sales can be ensured by expanding into foreign markets if the foreign market has potential for our products. Lack of information on competitors and customers results in oversized production capacity. Another reason may be to offer uninteresting products. The economic consequence is the cost increase as well as the underutilisation of fixed costs. The wave of global financial crises (2008-2009) caused a surge in the capital flows of developed countries particularly, between developed and developing countries.

The contribution is an output of the project VEGA 1/0619/20 Fundamental research of quantitative and qualitative determinants of enterprise innovation potential and innovation performance in relation to increasing its competitiveness.

\section{References}

1. Durana, P., Valaskova, K., Vagner, L., Zadnanova, S., Podhorska, I., Siekelova, A. (2020). Disclosure of Strategic Managers' Factotum: Behavioral Incentives of Innovative Business. International Journal of Financial Studies, 8(1), 17. 
2. Durana, P., Zauskova, A., Vagner, L., Zadnanova, S. (2020). Earnings drivers of slovak manufacturers: Efficiency assessment of innovation management. The European Physical Journal Applied Physics, Applied Sciences, 10(12), 42-51.

3. Cepel, M., Dvorsky, J., Gregova, E., Vrbka, J. (2020). BUSINESS ENVIRONMENT QUALITY MODEL IN THE SME SEGMENT. Transformations in Business \& Economics, 19(1), 262-283.

4. Ajaz Khan, K., Çera, G., Nétek, V. (2019). Perception of the Selected Business Environment Aspects by Service Firms. Journal of Tourism and Services, 10(19), 111 127.

5. Dengov, V. V., Gregova, E., Maksimov, A. V. (2016). Globalization in the Field of Food Retail St. Petersburg: analysis of the Price Policy. 16th GLOBALIZATION AND ITS SOCIO-ECONOMIC CONSEQUENCES, 362-374.

6. Whittle, T., Gregova, E., Podhorska, I., Rowland, Z. (2019). Smart Manufacturing Technologies: Data-driven Algorithms in Production Planning, Sustainable Value Creation, and Operational Performance Improvement. Economics, Management, and Financial Markets 14(2), 52-57.

7. Siekelova, A., Androniceanu, A., Durana, P., Frajtova-Michalikova, K. (2020). Earnings Management (EM), Initiatives and Company Size: An Empirical Study. Acta Polytechnica Hungaric, 17(9), 41-56.

8. Pisar, P., Bilkova, D. (2019). Controlling as a tool for SME management with an emphasis on innovations in the context of Industry 4.0. Equilibrium. Quarterly Journal of Economics and Economic Policy, 14(4), 763-785.

9. Michalkova, L., Frajtova Michalikova, K., Tanase, A. (2019). Factor analysis and its application in innovation management within manufacturing enterprises in Romania. Ekonomicko-manazerske spektrum, 13(2), 37-45.

10. Bednar, P., Halaskova, M. 2018. Innovation performance and R\&D expenditures in Western European regions: Divergence or convergence? Journal of International Studies, (1), 210-224.

11. Kliestik, T., Misankova, M., Valaskova, K., Svabova, L. 2018. Bankruptcy prevention: new effort to reflect on legal and social changes. Science and Engineering Ethics, 24(2), 791-803.

12. Cepel, M., Stasiukynas, A., Kotaskova, A., Dvorsky, J. 2018. Business Environment Quality Index in the SME Segment. Journal of Competitiveness, 10(2), 21-40.

13. La Rosa, F., Benini, F. 2018. Corporate governance and performance of Italian gambling SMEs during recession. International Journal of Contemporary Hospitality Management, 30(3), 1939-1958.

14. Kliestik, T., Majerova, J. 2015. Selected issues of selection of significant variables in the prediction models. In Financial management of firms and financial institutions: 10th international scientific conference, 537-543.

15. Mustafa, F., Khursheed, A., Fatima, M. (2018). Impact of global financial crunch on financially innovative microfinance institutions in South Asia. Financial Innovation, 4(1), 13 . 